\title{
Pengaruh Penambahan Enzim Kasar Polifenoloksidase dari Kulit Buah Kakao dan Ekstrak Pucuk Daun Kakao Terhadap Lama Fermentasi dan Mutu Biji Kakao
}

\author{
The Effect of Addition the Crude Polyphenoloxidase Enzymes from Cocoa Pod and Cocoa \\ Leaf Shoots Extract on Fermentation Time and Cocoa Beans Quality
}

\author{
Kalsum, Rosniati, dan Medan Yumas \\ Balai Besar Industri Hasil Perkebunan \\ Jl. Prof. Dr. Abdurrahman Basalamah No. 28 Makassar \\ e-mail: kalsum.bbihp@gmail.com
}

\begin{abstract}
One of the problems of national cocoa is the quality of cocoa beans is still low, as the aroma and distinctive taste of chocolate are lacking. This is due to the fermentation of cocoa beans are carried out imperfectly. This study aims to evaluate the effect of addition of the crude polyphenol oxidase enzyme from the cocoa pods and the extract of cocoa leaf shoots on fermentation time and quality of cocoa beans. The stages of this research are the preparation of nutrients, the preparation of crude enzyme polyphenol oxidase using the extracts of cocoa leaf shoots, carry out fermentation of cocoa beans for one day, two days and five days as a control that is without additions of crude enzyme polyphenol oxidase and the extract of cacao leaf shoots, do the testing, as well as carried out descriptive data analysis. The results showed that the cocoa beans were fermented for one day and two days have a fermentation index of 0.9998 and 1.0373; has a slety seed percentage of $1 \%$ and $0 \%$; has a fat content of 49,97\% and 50,04\%; in acccordance with the SNI 01-2323-200; cocoa beans were light brown in color and not moldy during storage for one month, three months and 5 months.
\end{abstract}

Key words: short fermentation, crude enzymes, polyphenol oxidase, cocoa beans

\begin{abstract}
ABSTRAK: Salah satu permasalahan kakao nasional adalah mutu biji kakao yang masih rendah yaitu aroma dan citarasa khas cokelat yang lemah. Hal tersebut dikarenakan biji kakao tidak difermentasi atau difermentasi tidak sempurna. Penelitian ini bertujuan untuk mengevaluasi pengaruh penambahan enzim kasar polifenol oksidase dari kulit buah kakao dan ekstrak pucuk daun kakao terhadap lama fermentasi dan mutu biji kakao. Tahapan penelitian meliputi pembuatan nutrient, pembuatan enzim kasar polifenol oksidase, ekstrak pucuk daun kakao, fermentasi biji kakao 1 hari, 2 hari serta kontrol 5 hari tanpa penambahan enzim kasar polifenol oksidase dan ekstrak pucuk daun kakao, pengujian dan analisis data secara desktriptif. Hasil penelitian menunjukkan bahwa biji kakao fermentasi 1 hari dan 2 hari memiliki indeks fermentasi 0,9998 dan 1,0373; memiliki presentase biji slaty 1\% dan 0\%; kadar lemak 49,97\% dan 50,04\%, memenuhi SNI 01-2323-200; warna biji kakao cokelat terang; tidak berjamur selama penyimpanan 1 bulan, 3 bulan dan 5 bulan.
\end{abstract}

Kata kunci: fermentasi singkat ,enzim kasar, polifenol oksidase, biji kakao

\section{Pendahuluan}

Kakao merupakan salah satu komoditi unggulan perkebunan Indonesia yang memegang peranan cukup penting dalam perekonomian Indonesia sebagai penghasil devisa negara, sumber pendapatan petani, penciptaan lapangan kerja, mendorong agribisnis dan agro industri. Komoditi kakao memberikan sumbangan dalam perolehan devisa sebesar US\$ 1,24 milyar dan merupakan penghasil devisa terbesar ketiga sub sektor perkebunan setelah kelapa sawit dan karet
(BPS Provinsi Sulawesi Selatan, 2019). Luas tanaman perkebunan kakao tahun 2018 di provinsi Sulawesi Selatan adalah 225114 ha dengan produksi 124332 ton (BPS Provinsi Sulawesi Selatan, 2019).

Buah kakao selain menghasilkan biji kakao, juga menghasilkan limbah kulit buah kakao lebih $70 \%$ (Alemawor et al., 2009), sehingga masih dimungkinkan untuk dilakukan diversifikasi dari kulit buah kakao. Matsumoto et al., (2004) menyatakan bahwa hasil ekstraksi polifenol dari kulit buah kakao diperoleh total 
polifenol sebanyak 12,6\%. Polifenol merupakan substrat bagi polifenol oksidase, dimana polifenol oksidase dipakai untuk meningkatkan aroma dari daun teh, biji kopi, dan biji kakao (Fang, 2007). Salah satu yang potensial untuk dikembangkan sebagai penghasil polifenol oksidase adalah fungi endofit yang hidup di dalam jaringan kulit buah kakao. Sartini (2011) telah berhasil mengisolasi fungi endofit Tricochothecium $s p$ yang terdapat di dalam jaringan kulit buah kakao secara in vitro sebagai penghasil polifenol oksidase dengan menggunakan media pembiakan fungi endofit. Penelitian sebelumnya menyatakan bahwa kulit buah kakao mengandung fungi endofit jenis Pleosporales sp., Xylariaceae, Pycnoporus $s p$, Phlebioid sp (Crozier et al., 2006), Colletotrichum gloeosporioides, Botryosphaeria ribis, Fusarium solani, Acremonium sp (Mejia, et.al, 2008).

Salah satu permasalahan perkakaoan nasional adalah mutu biji kakao yang masih rendah yaitu aroma dan citarasa khas cokelat yang lemah, berasa sepat (astringent) dan pahit (bitter) sehingga ketika diekspor ke mancanegara, khususnya ke negara-negara Eropa Barat dan Amerika Serikat sering kali mengalami pemotongan harga. Biji kakao yang baik dan sesuai standar perdagangan dunia adalah biji kakao terfermentasi sempurna, berbau khas cokelat, tidak mengandung kotoran dan serangga, serta jamur dengan batas toleransi (off-grade) kurang dari 3\% dari bobot keseluruhan (Rahmadi dan Fleet, 2008). Aroma dan citarasa khas cokelat yang lemah ini salah satunya diakibatkan karena biji kakao tidak difermentasi atau difermentasi tidak sempurna, penggunaannya pun hanya sebagai biji kakao pencampur pada proses "blending" karena memiliki lemak yang unik yaitu lemak yang tidak mudah meleleh. Salah satu faktor utama keengganan petani melakukan karena tidak adanya insentif harga untuk biji kakao yang difermentasi, selain itu memerlukan tambahan waktu proses dibandingkan jika biji kakao langsung dijemur.
Selama proses fermentasi biji kakao, akan terjadi penguraian senyawa polifenol, protein, dan gula oleh enzim yang akan menghasilkan senyawa bakal aroma, perbaikan citarasa, dan perubahan warna biji. Selang waktu fermentasi biji kakao secara spontan atau alami yang tepat adalah sekitar 5 hari untuk menghasilkan biji kakao berwarna coklat agak tua dan tekstur berongga (Mulato et al., 2007).

Polifenol oksidase termasuk golongan enzim oksidoreduktase yang mengandung atom tembaga $(\mathrm{Cu})$ dengan lignin, histidine pada sisi aktifnya (Queiroza et al., 2008), dilaporkan dapat meningkatkan aroma biji kakao (Fang, 2007), dan memperbaiki indeks fermentasi dan skor cut-test biji kakao yang difermentasi (Jinap et al., 2003). Enzim polifenol oksidase dapat dihasilkan melalui ekstraksi senyawa dari tanaman yang kaya polifenol seperti apel, murbei, tembakau, teh, dan kakao atau dengan memanfaatkan mikroorganisme yang terdapat di dalam jaringan tanaman itu sendiri.

Penelitian penambahan enzim kasar polifenol oksidase dari pulp kulit buah kakao sebagai starter pada proses fermentasi biji kakao telah dilaporkan oleh Rosniati et.al. (2013), dan La Teng dan Yunus (2015), namun penelitian yang akan dilakukan kali ini adalah fermentasi biji kakao dengan penambahan enzim kasar polifenol oksidase dari kulit buah kakao dan ekstrak pucuk daun kakao. Starter fermentasi diperkaya dengan nutrien hasil penelitian Sartini (2011), yang merupakan media pembiakan fungi endofit. Penambahan starter enzim kasar tersebut dapat mempersingkat waktu fermentasi dengan indeks fermentasi mendekati satu, dan mutu biji kakao kering yang dihasilkan kurang lebih sama dengan mutu biji kakao kering hasil fermentasi spontan selama lima hari (La Teng dan Yunus, 2015).

Penelitian ini bertujuan untuk mengevaluasi pengaruh penambahan enzim kasar polifenol oksidase yang dihasilkan dari jaringan kulit buah kakao dan ekstrak pucuk daun kakao terhadap 
waktu fermentasi biji kakao dan mutu biji kakao.

\section{METODOLOGI \\ Waktu dan Tempat Penelitian}

Penelitian ini dilakukan pada bulan Oktober-November 2019 di Balai Besar Industri Hasil Perkebunan Makassar.

\section{Bahan dan Alat}

Bahan yang digunakan pada penelitian ini adalah buah kakao, kulit buah kakao, pucuk daun kakao, etanol $70 \%$, nutrien, aquades, dan beberapa bahan kimia antara lain ragi instan, $\mathrm{KH}_{2} \mathrm{PO} 4$, $\mathrm{MgSO}_{4} 7 \mathrm{H}_{2} \mathrm{O}, \mathrm{CuSO}_{4} 5 \mathrm{H}_{2} \mathrm{O}$.

Alat utama yang digunakan adalah alat pemecah kulit buah kakao, blender merek Madato, termometer air raksa (0$100^{\circ} \mathrm{C}$ ), neraca analitik (sartorius), timbangan kapasitas $5 \mathrm{~kg}$, spektrofotometer uv/vis auto merk labomed. Inc. UV-2602 110 V. $60 \mathrm{~Hz} 220 \mathrm{~V}$. $50 \mathrm{~Hz}$ serial no. Auto 001637 labomed. Inc. USA, autoklaf, alat pengempa lemak kakao (hidrolik press), wadah untuk nutrien enzim kasar polifenol oksidase, waskom plastik, panci stainless steel, kompor gas, kotak fermentasi dari sterofoam kapasitas $10 \mathrm{~kg}$ biji basah sebagai pengganti kotak fermentasi, paranet/tikar plastik meja pengering biji kakao (para-para) dan pisau cutter.

\section{Metode Penelitian}

Metode yang digunakan dalam penelitian ini adalah fermentasi biji kakao dengan penambahan enzim kasar polifenol oksidase dari kulit buah kakao dan ekstrak pucuk daun kakao dengan waktu fermentasi 1 hari dan fermentasi 2 hari. Sebagai pembanding atau kontrol dilakukan fermentasi biji kakao secara alami selama 5 hari tanpa penambahan enzim kasar polifenol oksidase dan ekstrak pucuk daun kakao. Penelitian ini meliputi penyiapan bahan baku, penyiapan media starter (nutrient), pembuatan enzim kasar polifenol oksidase dari kulit buah kakao, fermentasi biji kakao, analisis indeks fermentasi biji kakao, analis kadar lemak biji kakao, analisis kadar biji slaty, dan analisis mutu biji kakao berdasarkan SNI 01-2323-2008 serta pengamatan warna dan jamur secara visual selama penyimpanan 1 bulan, 3 bulan, dan 5 bulan.

\section{Pembuatan media starter (nutrien)}

Bahan ragi instan (fermivan) $1 \%$, $\mathrm{KH}_{2} \mathrm{PO}_{4} \quad 0,1 \%$, $\mathrm{MgSO}_{4} 7 \mathrm{H}_{2} \mathrm{O} \quad 0,05 \%$, $\mathrm{CuSO}_{4} 5 \mathrm{H}_{2} \mathrm{O} \quad 0,1 \mathrm{M}$ (Sartini, 2011), dan ekstrak pucuk daun kakao sebagai pengganti asam galat. Bahan-bahan tersebut ditambahkan aquades $1000 \mathrm{ml}$ dan disterilkan pada autoklav dengan suhu $121^{\circ} \mathrm{C}$. Alur proses pembuatan media starter atau nutrient dapat dilihat pada Gambar 1.

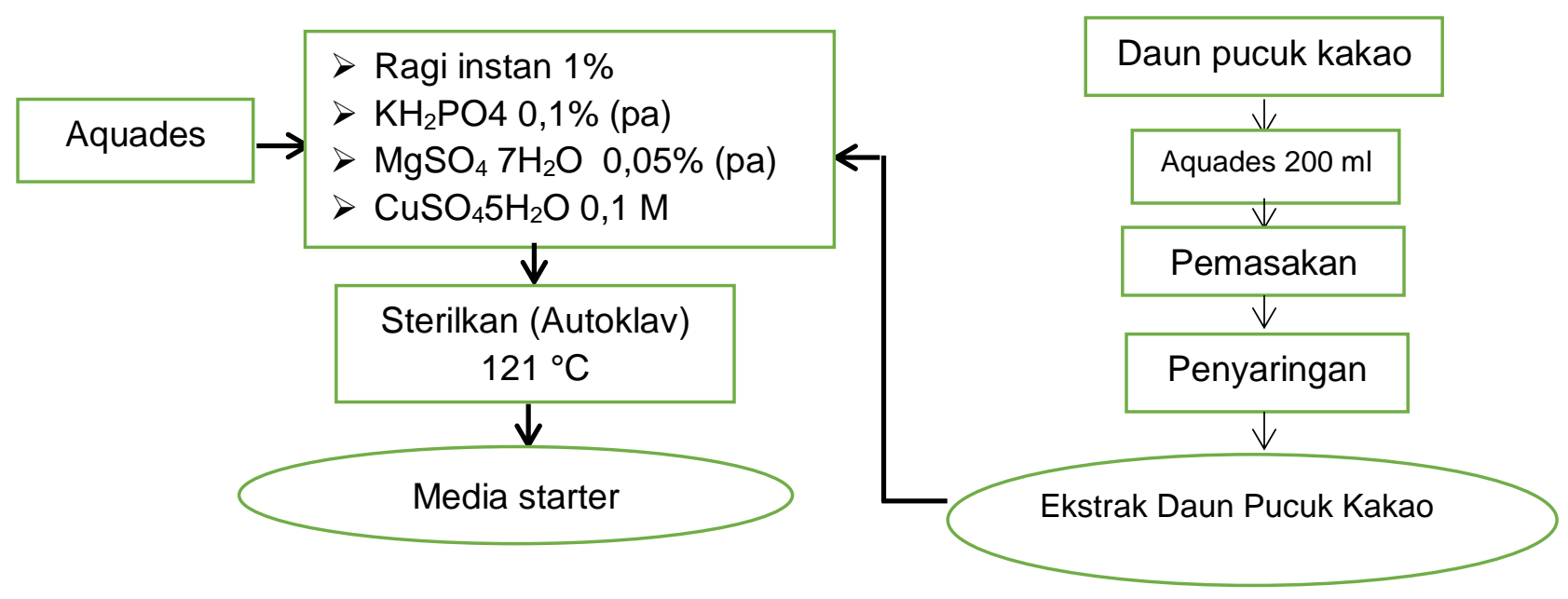

Gambar 1. Alur proses pembuatan media starter atau nutrient 
Pembuatan enzim kasar polifenol oksidase

Kulit buah kakao dicuci bersih menggunakan air dan ditiriskan hingga kering pada suhu ruang. Kulit buah kakao yang sudah kering dipotong kecil dengan ukuran kurang lebih $1 \times 3 \mathrm{~cm}$, selanjutnya dilakukan sterilisasi permukaan dengan etanol $70 \%$ selama 2 menit setelah itu dicuci kembali menggunakan aquades. Potongan kecil kulit buah kakao yang telah steril dihaluskan hingga menjadi bubur kulit buah kakao. Bubur kulit buah kakao yang telah terbentuk ditambahkan nutrient sebanyak $20 \mathrm{ml}$ dan diinkubasi selama 48 jam. Alur proses pembuatan enzim kasar polifenol oksidase dan ekstrak pucuk daun kakao dapat dilihat pada Gambar 2.

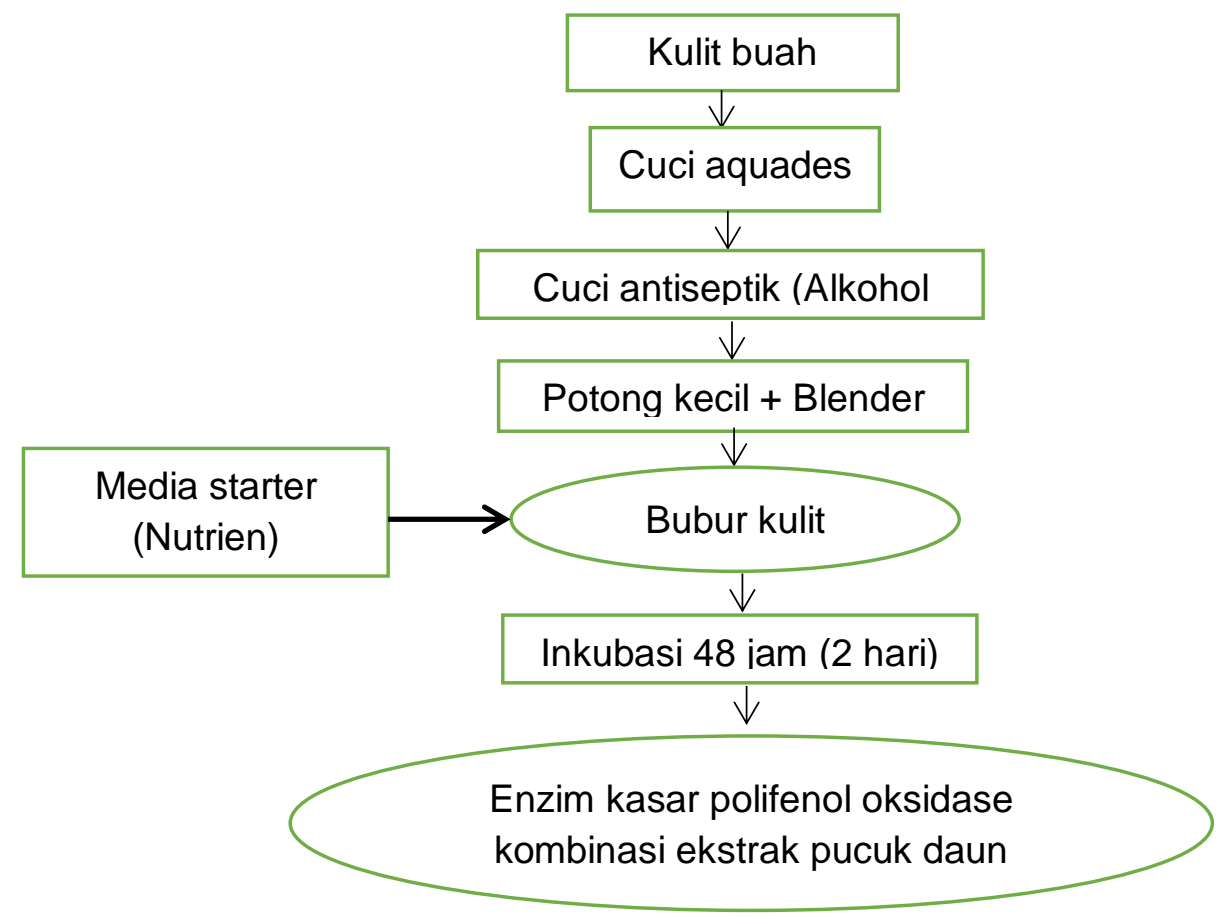

Gambar 2. Proses pembuatan enzim kasar polifenol oksidase kombinasi ekstrak pucuk daun kakao

\section{Fermentasi biji kakao}

Proses fermentasi biji kakao pada penelitian ini dikelompokkan menjadi tiga bagian yang masing-masing kotak fermentasi diisi biji kakao basah sebanyak $10 \mathrm{~kg}$ dengan tiga kali ulangan. (1) Fermentasi singkat biji kakao dengan penambahan enzim kasar polifenol oksidase dari kulit buah kakao dan ekstrak pucuk daun kakao selama 1 hari (F1). (2) Fermentasi biji kakao dengan penambahan enzim kasar polifenol oksidase dari kulit buah kakao dan ekstrak pucuk daun kakao selama 2 hari (F2). (3) Fermentasi biji kakao tanpa penambahan enzim kasar polifenol oksidase dari kulit buah kakao dan ekstrak pucuk daun kakao selama 5 hari sebagai kontrol (F3). Parameter yang diamati selama berlangsungnya proses fermentasi adalah suhu. Pengamatan dan pencatatan perubahan suhu biji kakao selama proses fermentasi dilakukan setiap 6 jam. Fermentasi biji kakao 1 hari (F1) dengan pembalikan biji kakao dilakukan setelah proses fermentasi berlangsung 12 jam dan setelah berlangsung 24 jam, biji kakao dikeluarkan dari kotak fermentasi lalu dicuci sebanyak 3 kali dan dijemur dibawah sinar matahari selama 4-5 hari hingga kadar air mencapai $7 \%$. Fermentasi 2 hari atau 48 jam (F2) dengan pembalikan biji kakao dilakukan setelah proses fermentasi berlangsung 24 jam dan setelah berlangsung 48 jam, biji kakao dikeluarkan 
dari kotak fermentasi lalu dicuci sebanyak 3 kali dan dijemur dibawah sinar matahari selama 4-5 hari hingga kadar air mencapai $7 \%$. Fermentasi alami 5 hari sebagai control (F3) dengan pembalikan dilakukan setelah proses fermentasi berlangsung 2 hari atau 48 jam dan setelah berlangsung selama 5 hari, biji kakao dikeluarkan dari kotak fermentasi, dicuci sebanyak 3 kali dan dijemur dibawah sinar matahari selama 4-5 hari hingga kadar air mencapai $7 \%$. Biji kakao yang kering dikemas ke dalam plastik sampel sebagaian disimpan selama 1 bulan, 2 bulan, dan 3 bulan untuk dilakukan uji warna dan jamur secara visual dan sebagian dilakukan untuk uji indeks fermentasi, dan analisis kadar lemak kakao, Alur proses fermentasi biji kakao dapat dilihat pada Gambar 3.

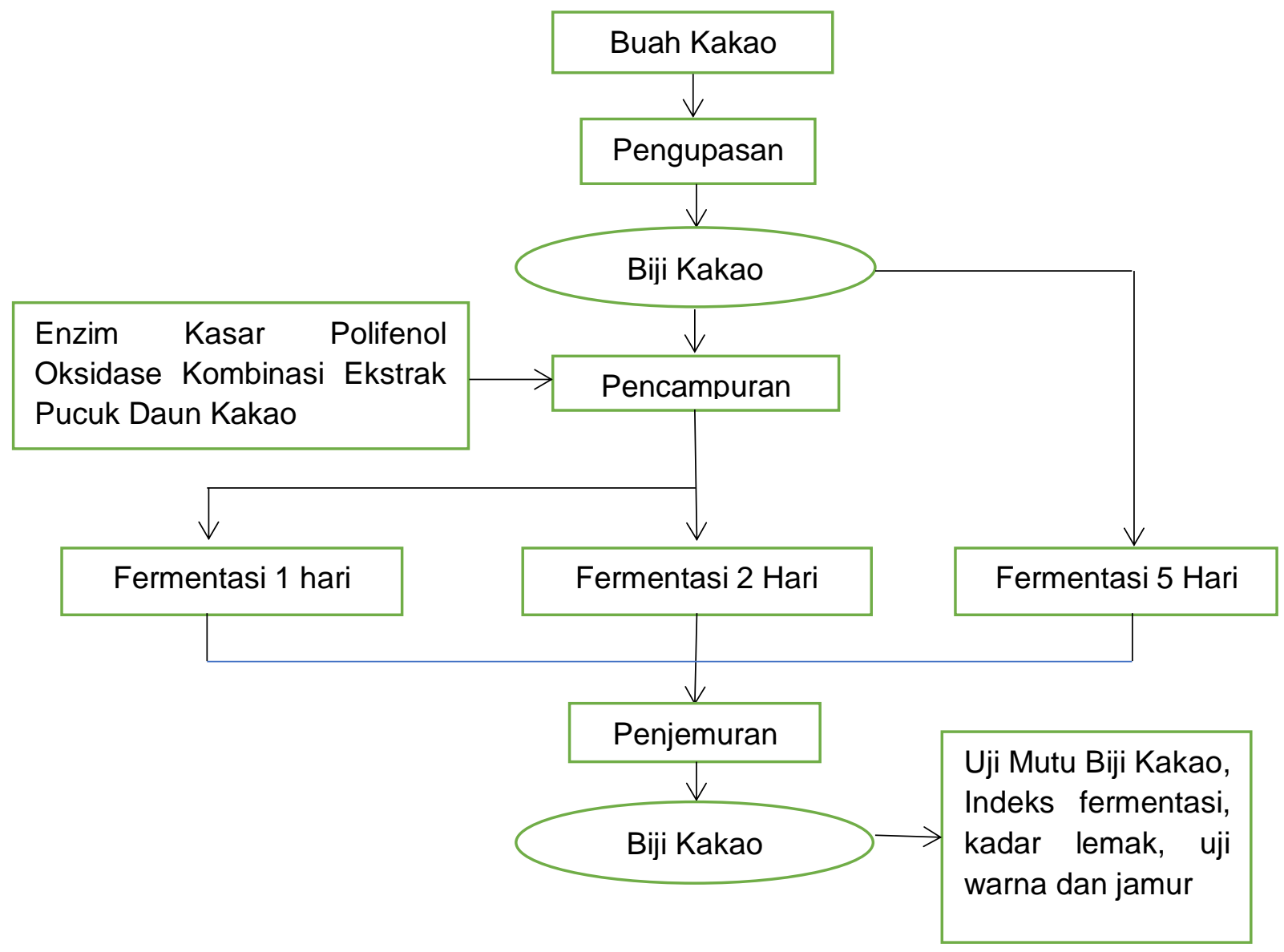

Gambar 3. Alur proses fermentasi biji kakao

Uji mutu biji kakao hasil fermentasi

Mutu biji kakao dilakukan dengan melihat persentase biji kakao tidak terfermentasi atau persentase biji slaty dengan metode cut-test menggunakan sampel 100 biji kakao kering hasil fermentasi yang diambil secara acak (SNI 01-2323-2008). Penentuan angka indeks fermentasi mengacu kepada metode Gourieva dan Tserevitinov (1979) dengan paten nomor 646254 yaitu membandingkan kadar flavonoid kompleks penyebab warna cokelat dengan kadar antosianin penyebab warna ungu melalui perbandingan absorbansi cahaya maksimum masingmasing senyawa pada panjang gelombang $460 \mathrm{~nm}$ dan $530 \mathrm{~nm}$.

HASIL DAN PEMBAHASAN

Suhu fermentasi biji kakao

Fermentasi biji kakao dimulai pukul 13.30 dengan suhu awal tumpukan biji 
kakao fermentasi untuk ke 3 (tiga) kotak fermentor sama dengan suhu lingkungan disekitarnya yaitu $32^{\circ} \mathrm{C}$ dan kemudian naik secara perlahan hingga mencapai suhu maksimum. Hasil pengukuran suhu di dalam fementor selama fermentasi berlangsung untuk perlakuan fermentasi 1 , 2, dan 5 hari dapat dilihat pada Tabel 1.

Tabel 1. Hasil pengukuran suhu fermentasi biji kakao untuk fermentasi 1, 2, dan 5 hari.

\begin{tabular}{cccc}
\hline $\begin{array}{c}\text { Durasi } \\
\text { Fermentasi }\end{array}$ & $(\mathrm{F} 1)$ & $\begin{array}{c}\text { Suhu }{ }^{\circ} \mathrm{C} \\
(\mathrm{F} 2)\end{array}$ & $(\mathrm{F3})$ \\
\hline 0 Jam & 32 & 32 & 32 \\
6 Jam & 35 & 36 & 33 \\
12 Jam & 39 & 38 & 35 \\
18 Jam & 45 & 44 & 37 \\
24 Jam & 45 & 44 & 40 \\
30 Jam & - & 45 & 41 \\
36 Jam & - & 46 & 42 \\
42 Jam & - & 46 & 43 \\
48 Jam & - & 45 & 43 \\
54 Jam & - & - & 44 \\
60 Jam & - & - & 44 \\
66 Jam & - & - & 45 \\
72 Jam & - & - & 45 \\
78 Jam & - & - & 47 \\
84 Jam & - & - & 47 \\
90 Jam & - & - & 46 \\
96 Jam & - & - & 44 \\
102 Jam & - & - & 44 \\
108 Jam & - & - & 43 \\
114 Jam & - & - & 43 \\
120 Jam & - & - & 40 \\
\hline
\end{tabular}

Pada Tabel 1 terlihat bahwa suhu biji kakao di dalam ketiga kotak fermentasi (F1,F2, dan F3) terus naik seiring dengan lama waktu fermentasi dan mencapai puncaknya setelah proses pembalikan biji kakao. Biji kakao pada kotak fermentasi pertama (F1) mencapai suhu puncak setelah proses fermentasi berlangsung 18 jam sebesar $45^{\circ} \mathrm{C}$, pada kotak fermentasi kedua (F2) mencapai suhu puncak setelah proses fermentasi berlangsung 36 jam sebesar $46^{\circ} \mathrm{C}$, dan kotak fermentasi ketiga (F3) suhu biji kakao mencapai puncak setelah fermentasi berlangsung 78 jam sebesar $47^{\circ} \mathrm{C}$. Terjadinya kenaikan suhu tumpukan biji kakao pada ketiga kotak fermentasi setelah pembalikan biji kakao disebabkan meningkatnya suplai oksigen atau volume oksigen yang masuk ke dalam kotak fermentasi. sehingga menimbulkan reaksi oksidasi asam cuka yang melepaskan panas lebih besar dibandingkan dengan panas yang dilepaskan oleh oksidasi alkohol oleh bakteri asam cuka (Amin, 2005). Panas yang dilepaskan tersebut akan menaikkan suhu masa kakao yang difermentasi sehingga mencapai suhu maksimal sekitar 
$45-47^{\circ} \mathrm{C}$ (Tabel 1). Fermentasi biji kakao yang berlangsung setelah pembalikan adalah fermentasi aerob, dimana pada kondisi aerob ini dimanfaatkan oleh bakteri asam asetat (Acetobakter) untuk mengubah alkohol menjadi asam asetat. Reaksi pembentukan asam asetat mempunyai sifat lebih eksotermis daripada reaksi pembentukan alkohol sehingga suhu tumpukan biji kakao pada ketiga kotak fermentasi setelah pembalikan cenderung meningkat (Tabel 1). Hal ini sejalan dengan hasil penelitian yang telah dilakukan Sukrisno (2004), Suprapti et al., (2002), Rosniati et al., (2003), Yumas (2010), dan Sarmidi (1993) bahwa suhu tumpukan biji kakao setelah pembalikan berangsur naik dan mencapai $45^{\circ} \mathrm{C}-50^{\circ} \mathrm{C}$ dan pada kondisi tersebut terjadi perubahan etanol menjadi asam asetat merupakan reaksi eksoterm yang dapat meningkatkan suhu $45^{\circ} \mathrm{C}$ sampai $50^{\circ} \mathrm{C}$, sesudah mencapai puncaknya suhu mulai mengalami penurunan.

Meskipun secara umum fermentasi 1 hari (F1), fermentasi 2 hari (F2), dan fermentasi 5 hari (F3) selaku kontrol, menunjukkan kecenderungan peningkatan suhu di dalam kotak fermentasi setelah dilakukan pembalikan, namun fermentasi biji kakao 1 hari (F1) dan fermentasi biji kakao 2 hari (F2) lebih cepat mencapai suhu optimum dibandingkan dengan fermentasi biji kakao 5 hari (F3) yang besarnya masing-masing adalah $46^{\circ} \mathrm{C}$ dan $47^{\circ} \mathrm{C}$ (Tabel 1). Tercapainya suhu optimum yang begitu cepat pada fermentasi 1 hari (F1) sebesar $46^{\circ} \mathrm{C}$ yang proses fermentasi baru berlangsung 18 jam dan fermentasi 2 hari (F2) sebesar $47^{\circ} \mathrm{C}$ yang proses fermentasi baru berlangsung 36 jam karena adanya penambahan enzim kasar polifenol oksidase dari kulit buah kakao dan ekstrak pucuk daun kakao yang berfungsi mengkatalisis oksidasi substrat yang mengandung senyawa fenolik tertentu membentuk senyawa-senyawa kuinon dan menggunakan oksigen sebagai ko-substrat. Selain itu enzim kasar polifenol oksidase dari kulit buah kakao dan ekstrak pucuk daun kakao juga berfungsi sebagai nutrient untuk memacu kerja bakteri untuk mempercepat proses penguraian alkohol menghasilkan asam asetat dan panas yang bersifat eksotermis. Pada saat dilakukan pembalikan atau pengadukan massa biji kakao pada fermentasi 1 hari setelah berlangsung 12 jam dan fermentasi 2 hari setelah berlangsung 24 jam, suplai oksigen yang masuk ke dalam kotak fermentasi meningkat. Asam asetat yang telah terbentuk dari penguraian alkohol oleh bakteri sebelum dilakukan pembalikan, akan teruai oleh adanya suplai oksigen setelah dilakukan pembalikan menjadi karbondioksida dan air dengan melepaskan panas. Akibat adanya panas yang dihasilkan dari proses penguraian bakteri menyebabkan naiknya suhu tumpukan biji kakao di dalam kotak fermentasi. Mulato, et al., (2007) menyatakan bahwa aktivitas reaksi dan suhu fermentasi terlihat mulai konstan setelah proses pembalikan dan proses fermentasi berlangsung 72 jam atau tiga hari.

\section{Mutu biji kakao fermentasi}

Hasil pengujian mutu biji kakao dengan waktu fermentasi satu hari, fermentasi dua hari dan fermentasi lima hari berdasarkan SNI 01-2323-2008 dapat dilihat pada Tabel 2.

Tabel 2. Hasil analisis standar mutu biji kakao fermentasi 1 hari, fermentasi 2 hari dengan penambahan enzim kasar polifenoloksidase dan ekstrak pucuk daun kakao dan fermentasi 5 hari (alami).

\begin{tabular}{clcccc}
\hline No. & Parameter uji & Satuan & F1 & F2 & F3 \\
& & & Syarat Umum & \\
\hline 1 & Serangga hidup & \% fraksi & Tidak ada & Tidak ada & Tidak ada \\
2 & Kadar air & 6,10 & 6,39 & 6,39 \\
3 & $\begin{array}{l}\text { Biji berbau asap atau } \\
\text { hummy dan atau } \\
\text { berbau asing }\end{array}$ & - & Tidak ada & Tidak ada & Tidak ada \\
\hline
\end{tabular}


Jurnal Industri Hasil Perkebunan Vol.15 No.2 Desember 2020: 63-74

\begin{tabular}{|c|c|c|c|c|c|}
\hline 4 & Kadar benda asing & - & $\begin{array}{c}\text { Tidak ada } \\
\text { Syarat khusus }\end{array}$ & Tidak ada & Tidak ada \\
\hline 1 & Kadar biji berjamur & $\%(b i j / / b i j i)$ & 4,00 & 3,33 & 1,00 \\
\hline 2 & Biji slaty & $\%(\mathrm{biji} / \mathrm{biji})$ & 1,00 & 0,00 & 0,00 \\
\hline 3 & $\begin{array}{l}\text { Kadar biji } \\
\text { berserangga }\end{array}$ & $\%(\mathrm{biji} / \mathrm{biji})$ & 0,33 & 0,00 & 1,00 \\
\hline 4 & $\begin{array}{l}\text { Kadar biji } \\
\text { berkecambah }\end{array}$ & $\%$ (biji/biji) & 3,47 & 3,40 & 3,27 \\
\hline 5 & $\begin{array}{l}\text { Kadar kotoran atau } \\
\text { waste }\end{array}$ & $\%$ (biji/biji) & 2,18 & 1,72 & 2,71 \\
\hline 6 & $\begin{array}{l}\text { Derajat keasaman } \\
(\mathrm{pH})\end{array}$ & & 5,78 & 5,60 & 5,42 \\
\hline 7 & Kadar lemak & $\%$ & 49,97 & 50,04 & 51,07 \\
\hline
\end{tabular}

Salah satu parameter uji untuk mengetahui fermentasi berlangsung secara sempurna adalah dengan cara melihat persentase biji slaty yang terjadi. Hasil uji biji kakao hasil fermentasi berdasarkan SNI 2323:2008 (Tabel 2) menunjukkan bahwa biji slaty pada fermentasi satu hari ditemukan sebanyak $1 \%$, sedangkan pada fermentasi dua hari dan fermentasi lima hari biji slaty ditemukan sebanyak $0 \%$. Hal ini menunjukkan bahwa fermentasi 1 hari dihasilkan biji kakao terfermentasi sempurna $99 \%$ dan untuk fermentasi 2 hari dan 5 hari dihasilkan biji kakao terfermentasi sempurna $100 \%$. Hasil penelitian ini sejalan dengan hasil penelitian yang dilakukan oleh La Teng dan Yunus (2015) menyatakan bahwa dengan menggunakan enzim polifenol oksidase yang diperkaya nutrient dapat mempersingkat waktu fermentasi dari 5 hari menjadi 16-40 jam. Tabel 2 juga menunjukkan bahwa baik fermentasi 1 hari, fermentasi 2 hari, dan fermentasi 5 hari ketiganya memenuhi syarat SNI 2323:2008 bahwa kadar biji slaty maksimum adalah $3 \%$. Terjadinya fermentasi sempurna pada fermentasi 1 hari dan fermentasi 2 hari dengan mutu yang tidak berbeda dengan fermentasi 5 hari disebabkan adanya pemberian enzim kasar polifenol oksidase dari kulit buah kakao dan ekstrak daun pucuk kakao. Enzim kasar polifenol oksidase dari kulit buah kakao dan ekstrak daun pucuk kakao sebagai media tumbuhnya fungi endofit penghasil enzim polifenol oksidase yang berfungsi mempercepat proses fermentasi biji kakao (Sartini, 2011; Lateng dan Yunus, 2015), sehingga waktu yang dibutuhkan untuk melakukan fermentasi menjadi singkat yaitu 24 jam dengan pembalikan biji kakao setelah berlangsung fermentasi 12 jam dan fermentasi 48 jam dengan waktu pembalikan biji kakao setelah berlangsung fermentasi 24 jam.

Menurut SNI 2323:2008 tentang syarat mutu biji kakao, biji kakao dikategorikan ke dalam mutu I bila mengandung biji kakao tidak terfermentasi maksimum 3\% artinya terdapat 3 biji slaty per 100 biji, sedangkan untuk mutu II dan mutu III mengandung biji kakao tidak terfermentasi masing-masing maksimum 6\% dan 20\% (SNI 2323:2008; BSN 2008). Tabel 2 terlihat bahwa pemberian enzim kasar polifenol oksidase dari kulit buah kakao dan ekstrak pucuk daun kakao dengan inkubasi 48 jam pada fermentasi satu hari maupun fermentasi dua hari menghasilkan biji kakao kategori mutu I karena memiliki persentase biji slaty lebih kecil dari 3\% (SNI 2323:2008; BSN 2008). Kulit buah kakao mengandung fungi endofit yang berfungsi sebagai penghasil enzim polifenol oksidase. Enzim polifenol oksidase yang mengkatalisis oksidasi substrat yang mengandung senyawa fenolik tertentu membentuk senyawasenyawa kuinon dan menggunakan oksigen sebagai ko-substrat (Sartini, 2011).

Pada tabel 2 dapat dilihat bahwa $\mathrm{pH}$ biji kakao hasil fermentasi satu hari dan hasil fermentasi dua hari dengan penambahan enzim kasar polifenol oksidase dari kulit buah kakao kombinasi ekstrak pucuk daun kakao yaitu 5,78 dan 5,60 . Pada saat fermentasi biji kakao 
berlangsung, asam-asam organik yaitu asam laktat dan asam asetat terdifusi ke dalam biji kakao menyebabkan penurunan pH biji kakao. Wood dan Lass (2001) menyatakan bahwa para pengolah kakao menghendaki $\mathrm{pH}$ biji kakao fermentasi antara 5,2-5,8 untuk menghasilkan cocoa butter yang berkualitas.

\section{Kadar lemak biji kakao hasil fermentasi}

Kadar lemak biji kakao hasil fermentasi satu hari (F1) dan fermentasi dua hari (F2) dengan penambahan enzim kasar polifenol oksidasi dab ekstrak pucuk daun kakao, serta fermentasi lima hari atau fermentasi secara alami berkisar antara $49,97-50,04 \%$ (Tabel 2). Hal ini menunjukkan bahwa biji kakao fermentasi 1 hari (F1) dan fermentasi 2 hari (F2) merupakan kategori biji kakao yang baik untuk dilakukan diversifikasi olahan produk kakao (makanan dan minuman). Menurut Mulato et al., (2005) bahwa kisaran kadar lemak biji kakao Indonesia adalah $48-52 \%$. Tabel 2 terlihat bahwa kadar lemak biji kakao fermentasi 1 hari dan fermentasi 2 hari tidak menunjukkan adanya perbedaan yang signifikan sehingga lama fermentasi tidak berpengaruh terhadap kandungan lemak biji kakao hasil fermentasi. Hal ini bisa terjadi karena selama proses fermentasi berlangsung baik fermentasi 1 hari maupun fermentasi 2 hari, khamir tidak menggunakan lemak kakao sebagai sumber energinya. Widayat (2015) menyatakan bahwa selama proses fermentasi berlangsung, khamir memperoleh energi dari sukrosa yang terkandung di dalam pulp kakao.

\section{Indeks fermentasi biji kakao}

Hasil analisis indeks fermentasi biji kakao yang difermentasi selama 1 hari dengan penambahan enzim kasar polifenol oksidase dan ekstrak pucuk daun kakao (F1), fermentasi biji kakao selama 2 hari dengan penambahan enzim kasar polifenol oksidase dan ekstrak pucuk daun kakao (F2), dan fermentasi biji kakao selama 5 hari atau fermentasi alami tanpa penambahan enzim kasar polifenol oksidase dan ekstrak pucuk daun kakao (F3) dapat dilihat pada Tabel 3.

Tabel 3. Hasil analisis indeks fermentasi biji kakao fermentasi 1 hari, fermentasi 2 hari, dan fermentasi 5 hari (alami)

\begin{tabular}{cccc}
\hline $\begin{array}{c}\text { Waktu } \\
\begin{array}{c}\text { Fermentasi } \\
\text { (Jam) }\end{array}\end{array}$ & F1 & Indeks Fermentasi (IF) & F3 \\
\hline 0 & 0,5839 & 0,5842 & 0,5840 \\
12 & 0,8924 & 0,8917 & 0,7627 \\
24 & 0,9998 & 0,9084 & 0,8216 \\
36 & - & 0,9415 & 0,8746 \\
48 & - & 1,0373 & 0,8925 \\
60 & - & - & 0,9237 \\
72 & - & - & 0,9985 \\
84 & - & - & 1,1932 \\
96 & - & - & 1,2472 \\
108 & - & - & 1,3527 \\
120 & - & - & 1,4015 \\
\hline
\end{tabular}

Tabel 3 menunjukkan bahwa fermentasi biji kakao 1 hari (F1) dan fermentasi biji kakao 2 hari (F2) dengan penambahan enzim kasar polifenol oksidase dan ekstrak pucuk daun kakao lebih cepat mencapai fermentasi sempurna dibandingkan dengan fermentasi 5 hari atau fermentasi alami (F3). Indeks fermentasi biji kakao dengan penambahan enzim kasar polifenol oksidase dan ekstrak pucuk daun kakao untuk fermentasi 1 hari (F1) sebesar 0,9998 dan untuk fermentasi 2 hari (F2) sebesar 1,0373 (Tabel 3), ini menunjukkan bahwa telah terjadi fermentasi sempurna. Tercapai fermentasi sempurna pada F1 dan F2 diduga adanya penambahan enzim kasar polifenol oksidase dan ekstrak pucuk daun kakao 
yang menyebabkan terjadinya kenaikan suhu (Tabel 1) sehingga mempercepat pula proses kematian pada biji kakao atau menghambat perkecambahan pada biji kakao. Nilai indeks fermentasi biji kakao kering fermentasi 1 hari (F1) dan fermentasi 2 hari (F2) yang diuji menggunakan spektrometer pada panjang gelombang $460 \mathrm{~nm}$ dan $530 \mathrm{~nm}$, menghasilkan nilai indeks fermentasi biji kakao kering hasil fermentasi yang relatif sama dengan uji cut test penentuan jumlah biji slaty atau biji tidak terfermentasi per 100 biji kakao kering hasil fermentasi (Tabel 2).

Fermentasi sempurna pada $\mathrm{F} 1$ dan F2 dicapai dengan waktu fermentasi biji kakao yang lebih singkat yaitu 24 jam dan 48 jam, dibandingkan dengan waktu fermentasi biji kakao secara alami (fermentasi 5 hari) tanpa penambahan enzim kasar polifenol oksidase dan ekstrak pucuk daun kakao. Waktu fermentasi biji kakao pada F1 dan F2 yang lebih singkat ini, diduga adanya aktifitas enzim kasar polifenol oksidase yang dihasilkan oleh fungi endofit yang hidup dan terdapat pada sel jaringan kulit buah kakao. Mekanisme kerja dari enzim polifenol oksidase ini adalah mengkatalisis oksidasi substrat yang mengandung senyawa fenolik membentuk senyawa-senyawa kuinon yang menggunakan oksigen sebagai ko substrat. Enzim polifenol oksidase ini juga mendegradasi polifenol menjadi senyawasenyawa pembentuk aroma khas cokelat dan citarasa khas cokelat, serta pembentuk warna cokelat pada biji kakao. Hal ini sejalan dengan pernyataan Atmana (2002) dan Brito (2004) bahwa terjadinya penurunan atau perubahan kadar polifenol karena terjadi senyawa pembentuk aroma dan warna yang baik dengan bantuan enzim polifenol oksidase. Selama proses fermentasi berlangsung, senyawa polifenol mengalami difusi, keluar dari keping biji, dimana antosianin dihidrolisis oleh enzim menjadi gula dan sianidin. Kondisi ini sesuai yang dilaporkan oleh Atmawijaya (1993), bahwa terjadi penurunan kadar polifenol dalam biji selama proses fermentasi berlangsung karena terjadi difusi senyawa polifenol ke luar dari keping biji.

\section{Uji Warna Biji Kakao Kering Hasil Fermentasi Singkat}

Hasil uji warna biji kakao kering hasil fermentasi 1 hari dan fermentasi 2 hari dengan penambahan enzim kasar polifenol oksidase dan ekstrak pucuk daun kakao dan fermentasi alami atau fermentasi 5 hari tanpa penambahan enzim kasar polifenol oksidase dan ekstrak pucuk daun kakao selama penyimpanan dengan pengamatan secara visual dapat dilihat pada Tabel 4.

Tabel 4. Hasil uji warna biji kakao setelah penyimpanan

\begin{tabular}{cccc}
\hline \multirow{2}{*}{ Perlakuan biji kakao } & \multicolumn{3}{c}{ Warna biji kakao setelah penyimpanan } \\
F1 & $\begin{array}{c}\text { Cokelat terang dan } \\
\text { tidak berjamur }\end{array}$ & $\begin{array}{c}\text { Cokelat terang dan } \\
\text { tidak berjamur }\end{array}$ & $\begin{array}{c}\text { Cokelat terang dan } \\
\text { tidak berjamur }\end{array}$ \\
F2 & $\begin{array}{c}\text { Cokelat terang dan } \\
\text { tidak berjamur }\end{array}$ & $\begin{array}{c}\text { Cokelat terang dan } \\
\text { tidak berjamur }\end{array}$ & $\begin{array}{c}\text { Cokelat terang dan } \\
\text { tidak berjamur }\end{array}$ \\
F3 & Cokelat agak gelap & Cokelat agak gelap & Cokelat agak gelap \\
& dan tidak berjamur & dan tidak berjamur & dan tidak berjamur \\
\hline
\end{tabular}

Tabel 4 terlihat bahwa F1 dan F2 dengan pemberian enzim kasar polifenol oksidase dan ekstrak pucuk daun kakao pada penyimpanan satu bulan, dua bulan, dan lima bulan menghasilkan biji kakao kering cokelat terang. Hal ini menunjukkan bahwa selama proses fermentasi berlangsung, enzim polifenol oksidase mendegradasi polifenol pada biji kakao, dimana warna biji kakao berubah dari ungu menjadi warna cokelat. Terbentuknya warna cokelat terang pada biji kakao F1 
dan biji kakao F2 (Tabel 4) diakibatkan waktu fermentasinya singkat dan adanya proses pengeringan biji kakao di bawah sinar matahari. Biji kakao hasil fermentasi 1 hari (F1) dan fermentasi 2 hari (F2) mengandung kadar air yang banyak. Tersedianya air yang tinggi di dalam keping biji kakao menyebabkan aktivitas enzim polifenol oksidase semakin aktif dalam pembentukan warna cokelat. Reaksi pencokelatan pada biji kakao terjadi ketika proses pengeringan biji kakao berlangsung di bawah sinar matahari. Aktifnya enzim polifenol oksidase ini di dalam biji kakao dan tersedianya oksigen dari udara luar pada saat proses pengeringan berlangsung maka oksigen akan masuk melalui kulit dan rongga-rongga yang terbentuk pada biji kakao sehingga oksigen akan berinteraksi dengan senyawa polifenol dan enzim polifenol oksidase menyebabkan terjadinya reaksi pencoklatan pada biji kakao. Hal ini didukung oleh pernyataan Marshall et al., (2000) bahwa enzim polifenol oksidase mengoksidasi senyawa polifenol menjadi senyawa kuinon yang akhirnya menjadi senyawa komplek melanin yang berwarna coklat.

\section{SIMPULAN}

Penambahan enzim kasar polifenol oksidase dari kulit buah kakao dan ekstrak pucuk daun kakao pada proses fermentasi biji kakao dapat meningkatkan mutu biji kakao hasil fermentasi dan mempersingkat waktu fermentasi biji kakao dari 5 hari (fermentasi alami) menjadi 24 jam dan 48 jam, dengan indeks fermentasi 0,9998 dan 1,0373 ; memiliki presentase biji slaty $1 \%$ dan 0\%; memenuhi SNI 01-2323-2008 sebagai syarat mutu biji kakao, serta warna biji kakao cokelat terang dan tidak berjamur untuk penyimpanan 1 bulan, 3 bulan dan 5 bulan.

\section{DAFTAR PUSTAKA}

1. Alemawor, F., Dzogbefia, V.P., Oddoye, E.O.K. and Oldham, J.H. (2009). Effect of Pleurotus osttreatus Fermentation on Cocoa Pod Husk Composition,: Influence of Fermentation Period and $\mathrm{Mn}^{2+}$ Supplementation on the Fermentation
Process. African Journal of Biotechnology 8 (9): 1950-1958.

2. Amin, A. S., 2005. Teknologi Pasca Panen Kakao Untuk Masyarakat Perkakaoan Indonesia. BPPT Pres Jakarta. ISBN : 979-3733-02-01.

3. Atmana, S.A. 2002. Proses Enzimatis Pada Fermentasi Untuk Perbaikan Mutu Kakao. Iptek Pemacu Pembangunan Bangsa. BPP Teknologi.

4. Atmawijaya. 1993. Genetic Engineering of Theobroma Cocoa and Molecular Studies on Cacao Defense Responses. The Pennysylvania State University. Graduate Degree Program in Integrative Biosciences Disertation.

5. Badan Standardisasi Nasional Indonesia, 2008. Biji Kakao SNI 2323-2008. Jakarta.Badan Standarisasi Nasional

6. Badan Pusat Statistik Provinsi Sulawesi Selatan. 2019. Provinsi Sulawesi Selatan Dalam Angka. BPS Provinsi Sulawesi Selatan.

7. Brito, E.S, Grasia, N.H.P. 2004. Use of a Proteolitic Enzyme in Cocoa (Theobroma cocoaL). Processing Brazilia Archieves of Biology and Technology an International Journal. 47 (4):553-558

8. Crozier, J., Thomas, S.E., Aime M.C, Evans, H.C., and Holmes, K.A. (2006). Molecular Characterization of Fungal Endophytic Morphospecies Isolated from Stems and Pods of Theobroma cacao. Plant Patholog. 55: 783-791.

9. Fang, C. (2007). Characterization of Polyphenol Oxidase and Antioxidants from Pawpant (Asimina Tribala) Fruits. Thesis University of Kentucky.

10. Gourieva, K.B., and Tserevitinov, O.B. 1979. Method of Evaluating The Degree of Fermentation of Cocoa Beans. USSR. Paten No. 646254

11. Jinap, S., Jamiah, B, dan Nazamid S. 2003. Effect of Incubation and Polyphenol Oxidase Enrichment on Color, Fermentation Index, Procyanidins and Astrigency of Unfermented and Partly Fermented Cocoa Beans, International, J of. Food Science and Technology. 38(3): 285-295.

12. La Teng, P.N., dan MR. Yunus (2015), Aplikasi Enzim Kasar Polifenol Oksidase dari Kulit Buah Kakao pada Proses Fermentasi Biji Kakao, Jurnal Industri Hasil Perkebunan, Vol. 10, No. 2, ISSN 19790023, Akreditasi LIPI No. 521/AU2/P2MILIPI/04/2013, Desember 2015 
13. Marshall, M.R., Kim, J., Wei, C. 2000. Enzimatic Browning in Fruits, Vegetables, and Sea Food. FAO.

14. Matsumoto, M., Tsuji, M., Okuda, J., Sasaki, H., Nakano, K., Osawa, K., Shimura, S., Ooshima. 2004. Inhibitory Effects of Cacao Bean Husk Extract on Plaque Formation in Vitro an in Vivo. Eur $J$ Oral Sci., 2112: 249-252.

15. Mejía, L.C., Rojas, E.I., Maynard, Z., Arnold, A.E., Kyllo, D., Robbins, N., \& Edward, A.H. (2008). Endophytic fungi as biocontrol agents of Theobroma cacao pathogens. Biological Control, xxx, 1-12. doi: 10.1016/j.biocontrol.2008.01.012.

16. Mulato, S., Atmawinata, Oskari, Yusianto. 2007. Rek Model Sentralisasi Pengolahan Kakao Rakyat Untuk Peningkatan dan Pemanfaatan Produk Samping. Puslitkoka, Jember.

17. Mulato, S., S. Widyotomo, Misnawi, dan E. Suharyanto. 2005. Pengolahan Produk Primer dan Sekunder Kakao. Pusat Penelitian Kopi dan Kakao Indonesia, Jember.

18. Queiroza, C., Lopes, M.L.M, Fialhoa, E., Valente-Mesquita, V.L. 2008. Polyphenol Oxidase: Characteristics and Mechanisms of Browning Control. Food Reviews International, 24:361-375

19. Rahmadi dan Fleet, G.H. 2008. The Occurance of Mycotoxigenic Fungi in Cocoa Beans from Indonesia and Quensland, Australia. Proc. Intem, Sem. on Food Science. University of Soegiyapranata, Semarang.

20. Rosniati, P.N. La Teng, N. Duma, Arifuddin, Ishak, Anshar, dan Suryani (2013), Laporan Penelitian dan Pengembangan Pemanfaatan Bahan Lokal (kedelai dan Jagung) Sebagai Bahan Substitusi Susu Bubuk dan Lesitin Dalam Pembuatan Produk Cokelat Batangan. Balai Besar Industri Hasil Perkebunan, Makassar

21. Rosniati, Dase, B.L., Moridon, F., Munandar, Rombe, M., Srirejeki, E., Multasan. 2003. Pengembangan Sistem Pengolahan dan Teknik Fermentasi Kakao Biji. Laporan Penelitian dan Pengembangan. Balai Riset dan Standarisasi Industri dan Perdagangan Makassar. Departemen Perindustrian dan Perdagangan.

22. Sarmidi, A. 1993. Proses Enzimatis Pada Fermentasi Untuk Perbaikan Mutu Kakao. Iptek Pemacu Pembangunan Bangsa.
BPPT. Laboratorium Teknologi Proses Puspitek Serpong.

23. Sartini, 2011. Optimasi Produksi dan Karakteristik Biokimia Polifenol Oksidase dari Isolat Terpilih Fungi Endofit Kulit Buah Kakao (Theobroma cacao L). Disertasi Program Pasca Sarjana, FMIPA, Universitas Hasanuddin.

24. Sukrisno. 2004. Panduan Lengkap Budidaya Kakao. Pusat Penelitian Kopi dan Kakao Indonesia. Jember.

25. Suprapti, Iskandar P, Moridon F, Masuri, Dase B, Malati, Gopal M. 2002. Diseminasi Teknologi Tepat Guna Untuk Perintisan Desa Percontohan Penghasil Biji Kakao Yang Dapat Memenuhi SNI. Laporan Penelitian Balai Industri Makassar. Departemen Perindustrian dan Perdagangan Makassar.

26. SNI 2323-2008. 2008. Standar Nasional Indonesia Biji Kakao. Jakarta: Dewan Standarisasi Nasional.

27. Yumas, M. 2010. Pengaruh Penambahan Kultur Campuran Terhadap Waktu Fermentasi Biji Kakao. Warta IHP Vol. 27 No. 2 Desember 2010. ISSN 0215-1243. 102/Akred-LIPI/P2MBI/10/2007.

28. Widayat, H.P. 2015. Karakteristik Mutu Biji Kakao Aceh Hasil Fermentasi Dengan Berbagai Interval Waktu Pengadukan. Jurnal Teknologi dan Industri Pertanian Indonesia. 7 (1) : 7-11.

29. Wood, G.A.R., dan Lass, R.A. 2001. Cocoa. 4th ed. Longman.London 